\title{
Evaluating apricots in riverside, California: identifying productive cultivars for a low-chill environment
}

\begin{abstract}
Six apricot (Prunus armeniaca) cultivars were evaluated for cropping performance in the low-chill environment of Riverside, CA during four crop seasons (2012 through 2015). We evaluated cultivars with high fresh fruit quality in current commercial use that range widely in bloom date. Chill accumulations at the Riverside site ranged from $161 \mathrm{~h}$ to $470 \mathrm{~h}$ during the study, providing opportunities to evaluated performance under sub-optimal chill conditions. In general, the trialed apricots were not well adapted to the Riverside environment. Irregular bud break and pre-bloom floral bud shed were symptoms common to five of the six trialed cultivars. Cultivar Blenheim was the exception, producing crop loads that required thinning even after a dormant season with only 161 chill hours. Bloom duration (first to full) for 'Blenheim' averaged 35d in the Riverside plot, leading to a similarly lengthy fruit maturation period. Of the six trialed apricots, only 'Blenheim' could be recommended for non-commercial planting in environments having chill accumulations similar to Riverside, CA.
\end{abstract}

Volume 7 Issue 6 - 2017

\author{
Craig A Ledbetter,' Robert R Krueger ${ }^{2}$ \\ 'United States Department of Agriculture, Agricultural Research \\ Service, USA \\ ${ }^{2}$ United States Department of Agriculture, National Clonal \\ Germplasm Repository, USA
}

\begin{abstract}
Correspondence: Craig A Ledbetter, USDA, Agricultural Research Service, San Joaquin Valley Agricultural Sciences Center, 961 I S. Riverbend Avenue, Parlier, CA, 93648-9757, USA,
\end{abstract}

Tel 559596 2817, Email craig.ledbetter@ars.usda.gov

Received: June 06, 2017 | Published: December 15, 2017

\section{Introduction}

Apricot (Prunus armeniaca) was a thriving tree crop in California during the first half of the $20^{\text {th }}$ century, with nearly $100,000 \mathrm{~A}$ under production at its peak in 1926 Foytik. ${ }^{1}$ Since that time, production acreage has declined steadily to its current level of approximately 10,000A. Harvested apricot volume in California has averaged just over 54,000T annually over the last three reported years Holcomb. ${ }^{2}$ Regions of production have shifted as well, with the bulk of the apricot industry now centered in the San Joaquin Valley near Patterson, CA, whereas previous production centers were varied, and extended throughout the milder coastal valleys from south of San Francisco Bay through San Benito county. Riverside County, in inland Southern California, was once a production center for apricot, with nearly 2,300A under production in $1950 \mathrm{Hesse}^{3}{ }^{3}$ While production acreage has declined in California, enthusiasm for the tasty early-season fruit has not diminished, and the percentage of annual tonnage used for fresh sales (38\%) is currently at an alltime high (B. Ferriera, President, Apricot Producers of California, personal communication). Poor fruit quality in the supermarket is a common concern for consumers interested in purchasing apricot, and a reason some consumers choose to attempt growing apricot at home. Consumers generally understand that the perish ability of ripe apricot demands that it be picked somewhat immature, enhancing shelf-life in the produce bin at the expense of high fruit quality at purchase. Home growers can wait to harvest at their leisure, obtaining the specific fruit maturity of these delicate fruit that they desire.

When apricot production began shifting from the mild coastal valleys to the hot San Joaquin Valley in the 1960s, available cultivars were not adapted to the harsher environment. High-quality cultivars grown in the coastal valleys such as 'Blenheim' developed pitburn in the high June temperatures when grown in the San Joaquin, making flesh unattractive for fresh fruit sales Tufts. ${ }^{4}$ Initial breeding efforts led to the development of pit-burn resistant cultivars such as 'Castleton' Weinberger ${ }^{5}$ and 'Patterson' Anderson, ${ }^{6}$ and increased apricot acreage throughout the San Joaquin Valley. Four more decades of apricot breeding led to many more new cultivars with improved characteristics and adaptation to the San Joaquin Valley environment. Besides the pit-burn resistance necessary for the high summer temperatures encountered in the Valley, the newer cultivars were also adapted to the higher winter chilling conditions prevalent there. Apricots (as well as other stone fruits) require a period of winter chilling $\left(<45^{\circ} \mathrm{F}\right)$ during dormancy for proper flowering and fruit set.

The chilling requirement varies considerably between cultivars, and growers attempt to match appropriate cultivars with the environment where they will be grown. When apricots are planted in locations where sufficient winter chilling is lacking, poor fruit set and irregular vegetative growth are frequently encountered. Several million consumers live in Southern California cities and there are many who would enjoy producing apricot in an urban environment. However, chill accumulation is lower in Southern California regions as compared with even the most southerly region of the San Joaquin Valley (Table 1). Hence, apricot cultivars that are productive in the San Joaquin Valley may or may not be productive in Southern California, depending on the specific region's annual chill accumulation, and the chill hour requirement of planted cultivars.

\section{The chilling requirement of any given cultivar must be determined empirically}

Actual known chill requirements of apricot cultivars are rare. Chill accumulation at any given site can be easily recorded and researchers interested in determining cultivar chill requirements strive to plant cultivar trials over a range of sites with variable chill accumulation in order to identify that site with a minimum of chill hours and still an adequate crop load. Typically, as data accumulate through increased acreage of cultivars under evaluation over a range of variable chill hour environments, growers learn the minimum chill hour requirements for desired cultivars. This would be the case for 'Blenheim' (Royal) apricot that has been evaluated for decades in numerous Southern California environments and found to be generally productive in locations with less than 400 chill hours Sidnam. ${ }^{7}$ Most printed values for cultivar chill requirements are only estimates shown in tree nursery catalogs (https://baylaurelnursery.com/apricots.html; http:// 
www.davewilson.com:8080/product-information/product/apricots) without any explanation of how specific chill requirements were determined. We are unaware of any published evaluations of apricot cultivar productivity across a range of locations with progressively lower chilling.

Because of the continued interest of consumers and homeowners in apricot cultivation throughout Southern California and the general lack of information on suitability of apricot cultivars for that purpose, an apricot evaluation trial was established in a low-chill environment at Riverside, CA. Commercially used apricot cultivars with high fresh fruit quality and variable bloom dates / fruit development periods were evaluated to determine their ability to bear fruit in a low-chill environment.

Table I Average and range of chill unit accumulation (hours $<45 \mathrm{oF}$ ) in various Southern San Joaquin Valley and Southern California cities, 2010 through 2015

\begin{tabular}{|c|c|c|c|}
\hline \multicolumn{4}{|c|}{ Chill hour accumulation } \\
\hline City & County & Average & Range \\
\hline \multicolumn{4}{|c|}{ Southern San Joaquin valley cities } \\
\hline Arvin - Edison & Kern & 859 & $535-983$ \\
\hline Kettleman City & Kings & 664 & $443-902$ \\
\hline Shafter & Kern & 1,223 & $1,096-1,432$ \\
\hline \multicolumn{4}{|c|}{ Southern California Cities } \\
\hline Camarillo & Ventura & 452 & $136-754$ \\
\hline Indio & Riverside & 361 & $236-452$ \\
\hline Irvine & Orange & 278 & $77-497$ \\
\hline Long Beach & Los Angeles & 403 & $249-602$ \\
\hline Moreno Valley & Riverside & 309 & $234-418 y$ \\
\hline Oxnard & Ventura & 276 & $|60-47|$ \\
\hline Pomona & Los Angeles & 437 & $189-629$ \\
\hline San Diego & San Diego & 100 & $45-207$ \\
\hline Santa Barbara & Santa Barbara & 263 & $90-422$ \\
\hline Santa Clarita & Los Angeles & 431 & $258-609$ \\
\hline Temecula & Riverside & 194 & $89-365$ \\
\hline
\end{tabular}

Data from UCDavis Fruit \& Nut Research \& Information website: http://fruitsandnuts.ucdavis.edu/Weather_Services/chilling_accumulation_ models/Chill Calculators/?type=chill

Only 3years data available, 2013-2015

\section{Materials and methods}

\section{Plot establishment and cultural practices}

The low-chill cultivar evaluation plot was established on the Agricultural Experiment Station of the University of California, Riverside (UCR) in Riverside, CA. The Burchell Nursery (Oakdale, CA) provided nursery stock for the trial. Six apricot cultivars ('Apache,' 'Blenheim' (aka 'Royal' or 'Royal Blenheim'), 'Helena,' 'Lorna,' 'Patterson' and 'Robada'), all on 'Nemaguard' rootstock, were planted as one year old dormant nursery stock in UCR Field

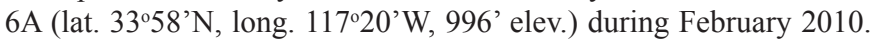
Five of the six apricot cultivars (exception 'Blenheim') are successful commercial cultivars grown throughout the San Joaquin Valley. 'Blenheim' is an older cultivar that is still produced commercially to a limited extent, but only in milder coastal valleys.
Specific chilling requirements for these six cultivars are unknown, but estimates for some cultivars have been provided by commercial sources (Table 2). The evaluation plot was planted using a basic rectangular design with rows representing the evaluated cultivars. Five trees of each cultivar were planted with a spacing of 10 ' between trees in the row, and 12' between rows (363trees/acre). The entire plot amounted to just $0.082 \mathrm{~A}$, and allowed sufficient space for trees of all cultivars to remain un crowded by neighboring trees during the study period. While the planting design would be considered statistically un replicated, the linear arrangement of cultivars facilitated the collection of basic data (tree vigor measurements, bloom phenology, ability to set fruit) and provided better photographic opportunities as compared with more robust experimental plot designs. Soil was classified as an Arlington fine sandy loam, well-drained, with the capacity to store 7.1" water in the soil profile. Field 6A was planted previously to citrus in the $1960 \mathrm{~s}$, and trees were removed several years prior to planting the apricot trial. Cultivars Apache, Helena, Lorna, Patterson and Robada were also available for study at the San Joaquin Valley Agricultural Sciences Center in Parlier, CA. Established trees of various ages, all grafted on 'Nemaguard' rootstock, were used for comparing bloom periods and fruit maturity seasons with trees grown at the UCR lowchill plot. 'Blenheim' apricot was not available for study at Parlier as the cultivar is not adapted to the high summer temperatures incurred there. Trees received water, as needed, through furrow irrigation. Specific pest control was unnecessary during the growing season during this study, but trees received an annual dormant oil \& copper fungicide spray prophylactically to control various insect and fungal pests. Weed control was accomplished through hand cultivation and disking between rows. No nutrients were applied to the low-chill plot from planting through its final harvest period in 2015. The majority of tree pruning occurred in summer each year after the fruit maturity season, generally during July, when trees were less susceptible to Eutypa dieback (Eutypa lata) Ramos et al. ${ }^{8}$ Summer pruning also opened the dense tree canopies to allow flower bud development for the following season's crop. Trees of all cultivars were shaped into open vases with four scaffolds.

Table 2 The evaluation plot was planted using a basic rectangular design with rows representing the evaluated cultivars

\begin{tabular}{llll}
\hline Units & & & \\
\hline $\begin{array}{l}\text { To Convert SI to U.S., } \\
\text { Multiply By }\end{array}$ & U.S. & SI & Multiply By \\
\hline 0.4047 & Acre(s) & ha & 2.47 II \\
0.3048 & $\mathrm{ft}$ & $\mathrm{m}$ & 3.2808 \\
2.54 & inch(es) & $\mathrm{cm}$ & 0.3937 \\
6.4516 & $\mathrm{In} 2$ & $\mathrm{~cm}^{2}$ & 0.155 \\
$(\mathrm{oF}-32) / 1.8$ & $\mathrm{OF}$ & $\mathrm{oC}$ & $(\mathrm{oC} * 1.8)+32$ \\
I.016 & Ton(s) & Tonne (s) & 0.9842 \\
\hline
\end{tabular}

\section{Data collection}

Chill hour accumulations were tracked using the Chill Calculator at the University of California Fruit \& Nut Research \& Information website(http://fruitsandnuts.ucdavis.edu/Weather_Services/chilling accumulation_models/Chill_Calculators/?type=chill) for stations 039 (Parlier, CA) and 044 (UC Riverside). Hours below $45^{\circ} \mathrm{F}$ were quantified from 1 November through 28/29 February for these locations in each dormancy period during the study. Trunk cross 
sectional area (TCSA $=p^{*}$ trunk radius2) was calculated from trunk circumference (Circumference $=2 * \mathrm{p}^{*}$ trunk radius) measurements taken 6" above the graft union. Measurements were made after summer pruning treatments and at the end of the growing season. First and full bloom dates were recorded for each cultivar. First bloom date was recorded when the first visible open flower was observed.

Full bloom date was recorded when approximately $80 \%$ of flowers on a tree were open. Typically at this date, some petal fall was also evident. Bloom data were collected at the UCR plot for comparison with similar data collected from trees growing in Parlier, CA. However, 'Blenheim' was not represented in Parlier and only bloom data from UCR were available for this cultivar. Fruit production was assessed in each of four crop seasons (2012- 2015), noting each cultivar's ability to set fruit and the relative maturity season. 'Blenheim' was evaluated for fruit quality during the 2012 harvest season. Twenty fruit were harvested from each of the five 'Blenheim' trees and brought to Parlier for analysis. Upon arrival, seven unblemished representative fruit were selected for evaluation from each tree. Skin was removed from a section of the cheek of each fruit for flesh color evaluation.

A chroma meter (CR-400; Konica Minolta Col Ltd., Osaka, Japan) was used to measure hue angle $\left(\mathrm{h}^{\circ}\right)$ of the apricot flesh. Fruit firmness was then measured on the skin-removed cheek of each fruit using a handheld penetrometer equipped with an 8-mm tip (D. Ballauf Mfg. Co., Washington DC). Longitudinal sections of each fruit were cut and combined for juicing to provide estimates of total soluble solids, juice $\mathrm{pH}$ and juice acidity. Presented values represent the average and standard deviation of five single-tree replications harvested from the 2012 crop.

\section{Results}

\section{Tree vigor at UCR}

Climatic conditions at UCR allowed tree growth to continue later in the year as compared with trees grown in Parlier, CA. Actively growing meristems and a lack of senescing leaves were observed on all cultivars in the Riverside plot at the end of December. By contrast, active vegetative growth of apricot became rare in the Parlier environment after early November, and most leaves had fallen from trees of all cultivars before November's end. Tree vigor varied dramatically among cultivars (Figure 1). At the end of the study, trunk cross sectional area of 'Helena' trees averaged $154 \mathrm{~cm}^{2}$, more than double the average trunk area of the least vigorous cultivar Robada $\left(71 \mathrm{~cm}^{2}\right)$. Vegetative growth of all cultivars proceeded normally with growth persisting throughout the long growing seasons.

\section{Bloom interval}

Bloom timings and durations were distinctly different between the Parlier and Riverside locations. For any given cultivar, bloom always began at an earlier date in Parlier as compared with Riverside. Without exception, bloom duration (first bloom to full bloom) was substantially longer in Riverside as compared with Parlier for any given cultivar. During harvest years 2012 through 2015, bloom duration averaged from $11.5 \mathrm{~d}$ (Helena) to $16.75 \mathrm{~d}$ (Robada) in Parlier, whereas the average bloom duration ranged from 16.25d (Patterson) to $35.5 \mathrm{~d}$ (Blenheim) in the Riverside plot during the same harvest seasons (Table 3). Across cultivars, bloom interval at Parlier averaged $14 \mathrm{~d}$ whereas the bloom interval at UCR averaged $23.25 \mathrm{~d}$. Across locations, 'Patterson' had the most rapid bloom interval (14.1d) and 'Apache' proved to have the lengthiest (20.5d). Delayed bloom period and extended bloom duration were shown to be common symptoms in peaches of insufficient chilling received during dormancy Weinberger. ${ }^{9}$

'Apache' was consistently the earliest blooming cultivar at Parlier and 'Robada' the latest. At UCR, 'Blenheim' consistently began bloom prior to 'Apache,' commencing $19 \mathrm{~d}$ and $18 \mathrm{~d}$ ahead during the 2014 and 2015 blooms, respectively (Table 3 ). These conditions were observed after two very low-chill dormancy periods before the 2014 and 2015 crop seasons where only 173 and 161 chill hours were received, respectively (Figure 2). It was unfortunate that 'Blenheim' was not represented in Parlier to observe its bloom date and duration under higher winter chill conditions.

Table 3 First and full bloom dates with durations (d) of six apricot cultivars grown in Parlier and Riverside, CA for four harvest years

\begin{tabular}{|c|c|c|c|c|c|}
\hline \multicolumn{6}{|c|}{ Harvest Year } \\
\hline Location & Cultivar & 2012 & 2013 & 2014 & 2015 \\
\hline \multirow{5}{*}{ Parlier } & Apache & 6-24 Feb- 19 & I5 Feb-I Mar-15 & 10 Feb-6 Mar-25 & 13-19 Feb-7 \\
\hline & Helena & $16-28 \mathrm{Feb}-13$ & 28 Feb-10 Mar - II & 24 Feb-4 Mar-9 & 17 Feb-I Mar-13 \\
\hline & Lorna & 13-28 Feb-16 & 25 Feb-9 Mar-13 & 19 Feb-3 Mar- 12 & 17-28 Feb-12 \\
\hline & Patterson & $16-28$ Feb-13 & 25 Feb-7 Mar-II & |8-28 Feb-|| & 17 Feb-I Mar-13 \\
\hline & Robada & 23 Feb-16 Mar-22 & 2-14 Mar-14 & 25 Feb-10 Mar-14 & 19 Feb-7 Mar- 17 \\
\hline \multirow{6}{*}{ Riverside } & Apache & 27 Feb-25 Mar-28 & 2-22 Mar-2I & 4 Mar-25 Mar-22 & 7 Mar-2 Apr-27 \\
\hline & Blenheim & 23 Feb-20 Mar-27 & 28 Feb-5 Apr-37 & 13 Feb-26 Mar-42 & 17 Feb-24 Mar-36 \\
\hline & Helena & 10 Mar-28 Mar-19 & 6 Mar-29 Mar-24 & 26 Mar-4 Apr-10 & 23 Mar-8 Apr- 17 \\
\hline & Lorna & 8 Mar-26 Mar-19 & 4 Mar-5 Apr-33 & 12 Mar-7 Apr-27 & 15 Mar-5 Apr-22 \\
\hline & Patterson & 6 Mar- 18 Mar- 13 & $9-22$ Mar-14 & II-28 Mar-18 & 14 Mar-2 Apr-20 \\
\hline & Robada & 13-30 Mar-18 & 14 Mar-5 Apr-23 & 14 Mar-3 Apr-2I & 17 Mar-5 Apr-20 \\
\hline
\end{tabular}




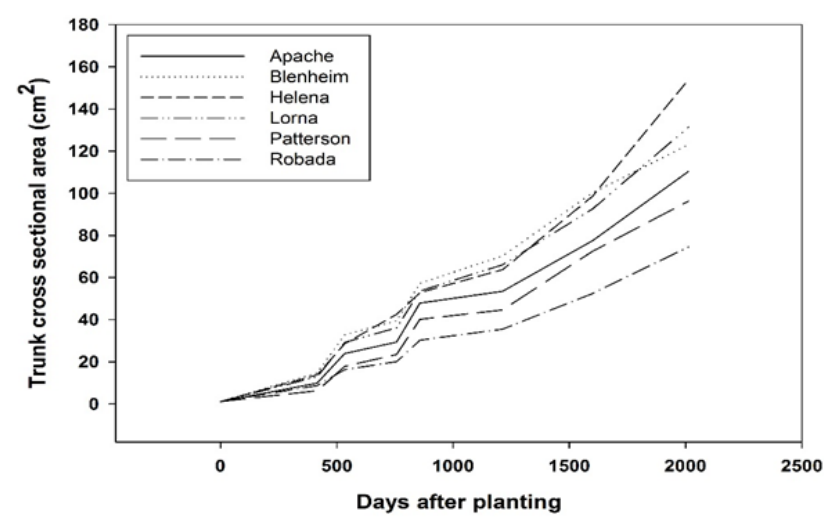

Figure I Cumulative trunk cross sectional area $\left(\mathrm{cm}^{2}\right)$ changes of six apricot cultivars grown in Riverside, CA for five seasons, $2010-2015 .\left(\mathrm{cm}^{2} *\right.$ $\left.0.1550=\mathrm{in}^{2}\right)$

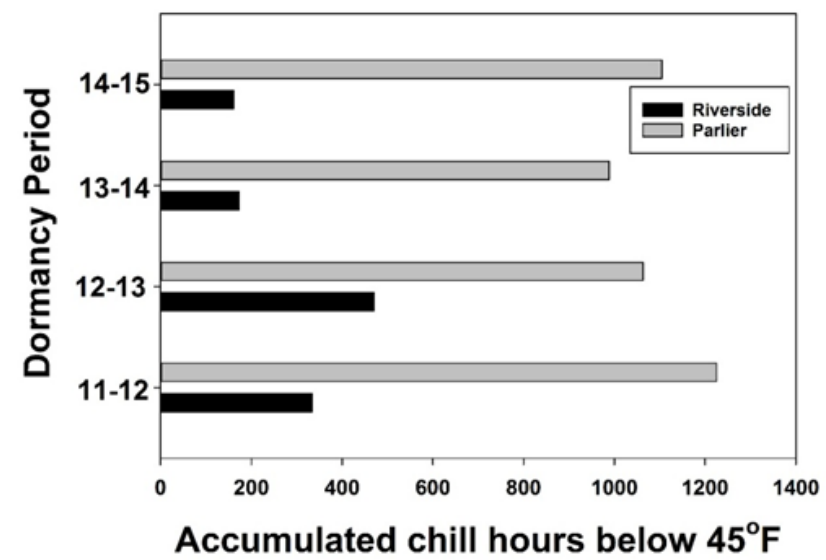

Figure 2 Chill hour accumulation in Parlier, CA and Riverside, CA for dormancy periods prior to crop years 2012 through 2015.

\section{Cropping ability}

At the Riverside plot, fruit production was very inconsistent for five of the six trialed cultivars, the same cultivars that produced adequate yields in San Joaquin Valley orchards. Fruit production was very limited in these cultivars, and while they would certainly not be useful for commercial production in Riverside, their utility for backyard production might also be questioned (Table 4). The progression of fruit maturity observed among these cultivars at UCR was the same as what had been consistently observed in Parlier. 'Blenheim' was the exception at Riverside, and all 'Blenheim' trees required extensive fruit thinning in each harvest season for adequate fruit sizing (Figure 3). While somewhat small (40.9g) for commercial markets, fruit quality of 'Blenheim' produced at UCR was very good, averaging $19.2 \%$ total soluble solids from fruit having $12.8 \mathrm{~N}$ flesh firmness (Table 5). The low acidity observed in 'Blenheim' coupled with the relatively high total soluble solids led to an impressive 43.6 Brix: Acid ratio, indicative of good eating quality. Pit-burning was not observed in mature 'Blenheim' fruit, nor in the small amounts of fruit produced by any of the other five trialed cultivars at that plot. The fruit maturity season for 'Blenheim' was much extended as compared with the other cultivars, presumably due to its unusually lengthy bloom period (Figure 3). Because of the inconsistency of fruit production when grown under the environmental conditions at Riverside, cultivars Apache, Helena, Lorna, Patterson and Robada could not be recommended for planting there or in other low-chill areas of Southern California. Cultivar Blenheim can be recommended for planting, as it produced consistently at the Riverside location, even after receiving as few as 161 chill hours during dormancy.

Table 4 Flowering and cropping abilities of six apricot cultivars cultivated at a low-chill site in Riverside, CA during crop years 2012 through 2015

\begin{tabular}{|c|c|c|c|}
\hline Cultivar & $\begin{array}{l}\text { Pre fruit set } \\
\text { development }\end{array}$ & Cropping ability & $\begin{array}{l}\text { Recommended } \\
\text { for low Chill } \\
\text { Site }\end{array}$ \\
\hline \multirow[t]{3}{*}{ Apache } & $\begin{array}{l}\text { Abundant flower } \\
\text { buds }\end{array}$ & $\begin{array}{l}\text { Higher fruit loads } \\
\text { in years with } \\
\text { higher chilling }\end{array}$ & No \\
\hline & $\begin{array}{l}\text { Irregular } \\
\text { vegetative bud } \\
\text { break }\end{array}$ & \multicolumn{2}{|c|}{ Thinning never required } \\
\hline & \multicolumn{3}{|c|}{ Generally weak bloom strength } \\
\hline \multirow[t]{2}{*}{ Blenheim } & $\begin{array}{l}\text { Strong extended } \\
\text { blooms }\end{array}$ & $\begin{array}{l}\text { Highest fruit loads } \\
\text { of the trialed } \\
\text { cultivars }\end{array}$ & Yes \\
\hline & $\begin{array}{l}\text { Distinct 'waves' } \\
\text { of bloom with } \\
\text { developing fruit } \\
\text { \& bloom present } \\
\text { on tree at same } \\
\text { time }\end{array}$ & \multicolumn{2}{|c|}{ Always required extensive thinning } \\
\hline \multirow[t]{2}{*}{ Helena } & $\begin{array}{l}\text { Most vigorous } \\
\text { cultivar, } \\
\text { vegetatively }\end{array}$ & $\begin{array}{l}\text { Higher fruit loads } \\
\text { in years with } \\
\text { higher chilling }\end{array}$ & No \\
\hline & $\begin{array}{l}\text { More intense } \\
\text { bloom in higher } \\
\text { chill years }\end{array}$ & \multicolumn{2}{|c|}{$\begin{array}{l}\text { Thinning was never required } 0-15 \text { fruit } \\
\text { per tree per season }\end{array}$} \\
\hline \multirow[t]{3}{*}{ Lorna } & $\begin{array}{l}\text { Generally good } \\
\text { flower bud } \\
\text { development }\end{array}$ & $\begin{array}{l}\text { Poor cropping } \\
\text { ability, even at } 470 \\
\text { chill hours }\end{array}$ & No \\
\hline & $\begin{array}{l}\text { Irregular } \\
\text { vegetative bud } \\
\text { break }\end{array}$ & \multicolumn{2}{|c|}{$0-5$ fruit per tree per season } \\
\hline & \multicolumn{3}{|c|}{ Pre-bloom bud sluffing } \\
\hline \multirow[t]{2}{*}{ Patterson } & $\begin{array}{l}\text { Abundant flower } \\
\text { buds }\end{array}$ & $\begin{array}{l}\text { Consistent across } \\
\text { years to produce } \\
\text { some fruit }\end{array}$ & No \\
\hline & $\begin{array}{l}\text { Shortest mean } \\
\text { bloom duration } \\
\text { (16 d) of } \\
\text { cultivars at site }\end{array}$ & \multicolumn{2}{|c|}{$\begin{array}{l}\text { Thinning was never required } 3-30 \text { fruit } \\
\text { per tree }\end{array}$} \\
\hline \multirow[t]{3}{*}{ Robada } & $\begin{array}{l}\text { Weakest } \\
\text { of cultivars, } \\
\text { vegetative }\end{array}$ & $\begin{array}{l}\text { Poorest cropping } \\
\text { of trialed cultivars }\end{array}$ & No \\
\hline & $\begin{array}{l}\text { Poorest of } \\
\text { cultivars in } \\
\text { bloom strength }\end{array}$ & \multicolumn{2}{|c|}{$\begin{array}{l}\text { Less than } 15 \text { fruit set on five trees in } \\
\text { four crop seasons }\end{array}$} \\
\hline & \multicolumn{3}{|c|}{ Latest blooming cultivar } \\
\hline
\end{tabular}




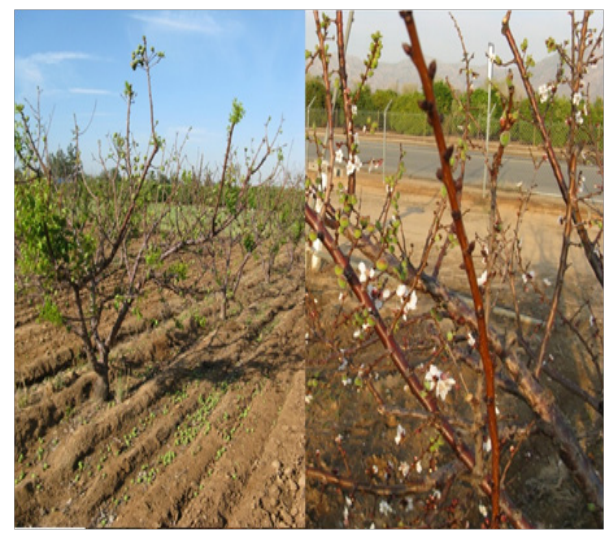

Figure 3 Blenheim' apricot trees cultured in Riverside, CA during 2014 produced abundant crops that required thinning, even with as few as 173 chill hours (left). Bloom duration was extended under reduced chill hour conditions, leading to cultivar Blenheim with flower buds, open flowers and developing fruit evident on the same tree (right).

Table 5 Fruit physical characteristics and juice chemistry for 'Blenheim' apricot harvested in Riverside, CA during the 2012 harvest season

\begin{tabular}{ll}
\hline Characteristic & Blenheim \\
\hline Fruit Physical Character & \\
Fruit mass (g) & $40.9 \pm 1.0$ \\
Axial diameter (mm) & $42.1 \pm 0.7$ \\
Flesh firmness (N) & $12.8 \pm 0.7$ \\
Flesh hue (o) & $73.8 \pm 0.6$ \\
Juice Chemistry & \\
Total soluble solids (\%) & $19.2 \pm 0.3$ \\
pH & $3.78 \pm 0.08$ \\
Acidity (Meq/I00mL) & $0.44 \pm 0.04$ \\
Fruit harvest date & $12-\mathrm{Jun}$ \\
\hline
\end{tabular}

\section{Discussion}

While there were over $2300 \mathrm{~A}$ of apricot produced in Riverside County as late as 1950 Hesse, ${ }^{3}$ apricot production amounted to just $38 \mathrm{~T}$ in Riverside County in 2014, accounting for only 17A of the County's 26,000 A of tree and vine crops Anon. ${ }^{10}$ Chill hour accumulation varied dramatically between the Parlier and UCR locations during the course of this study (Figure 2). Chill accumulation received at Parlier during the past 10 dormant seasons averaged 1132h. Average chill accumulation during the same period at UCR was only $315 \mathrm{~h}$, less than a third of that received at Parlier. Chill accumulations were well below average prior to the 2014 and 2015 crop seasons at UCR, with only $173 \mathrm{~h}$ and $161 \mathrm{~h}$ received, respectively.

Chill hours received at Parlier ranged from 989h (2013) to 1225h (2011) during the study years, well above expected chill requirements for the apricots under cultivation. Five of the six trialed apricot cultivars (exception 'Blenheim') consistently produce adequate yields for commercial production under the environmental conditions present in and around Parlier, CA. High quality 'Blenheim' apricot is still produced on limited acreage in the mild coastal valleys, with 1,400 T (3\% of 2016 tonnage) produced statewide in 2016 (B. Ferriera, President, Apricot Producers of California, personal communication). Vegetatively, apricot cultivars grew well at the UCR plot, responding to the long growing season that allowed for growth later into the calendar year as compared with growing conditions at Parlier. Adequate summer pruning after the fruit maturity season provided required light for developing flower buds (Figure 4), and all cultivars exhibited well developed flower buds on dormant shoots and spurs while in vegetative dormancy.

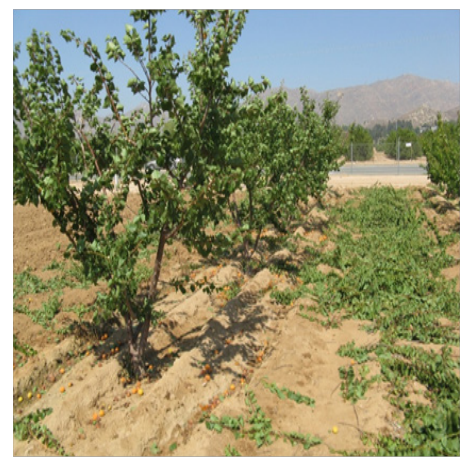

Figure 4 Abundant fruit drop is evident below 'Blenheim' trees cultured in Riverside, $C A$ in 2012. Trees were vigorously pruned after harvest to provide light necessary for proper flower bud development.

Major differences between trees at the two plots became apparent each year as temperatures began to warm and flower buds began to push. Apricot cultivars cultured in Parlier came into bloom with a full complement of floral buds, producing dense blooms throughout the trees. Vegetative bud break was relatively synchronous throughout the trees of each cultivar, and bloom durations were shorter as compared with the same cultivars planted at UCR. Apricots cultured at UCR by contrast began losing floral buds throughout the trees as temperatures began to warm. Pre-bloom flower bud shedding in apricot has been previously documented as a symptom of insufficient winter chill accumulation Tufts. ${ }^{4}$ Bloom density was weak in trees of all cultivars except 'Blenheim,' which seemed unaffected by dormant periods with reduced chill accumulation. Irregular vegetative bud break was a common symptom among trialed cultivars grown at UCR (Figure 5). This phenomenon has been previously documented in peaches when winter chill was insufficient for the planted cultivars Weinberger. ${ }^{9}$ Vegetative bud break appeared more uniform in 'Blenheim,' indicating a lower chill requirement as compared with the other five trialed cultivars.

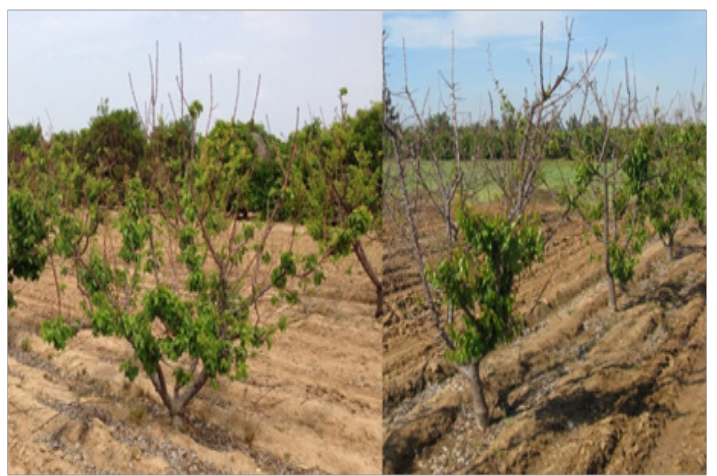

Figure 5 Appearance of 'Lorna' (left) and 'Apache' (right) trees in April 20I4 after receiving only 173 chill hours. Both cultivars demonstrate irregular vegetative bud break with large parts of scaffolds devoid of vegetation.

Based on bloom and fruit production data from four crop seasons, five of the six evaluated cultivars could not be recommended for 
planting in Riverside, CA. Chill accumulation at that location was generally insufficient for those five cultivars. However, higher fruit loads were noted in some cultivars ('Apache,' 'Helena' and 'Patterson') in years where higher chilling was received. Performance of these cultivars might be adequate, at least for non-commercial homeowner production, in locations having a higher average chill accumulation as compared with UCR. These locations would probably be found at higher elevations in Southern California, such as the local mountains; as it is unlikely that any low elevation areas in Southern California would have sufficient chilling for apricot cultivars other than 'Blenheim'. Cultivar Blenheim appears perfectly suitable for non-commercial production in environments with similar chill hours received at UCR. Its extended bloom period might actually be an added bonus for homeowners who would appreciate an extended harvest period, and have fresh ripe apricot available for immediate use.

\section{Acknowledgements}

None.

\section{Conflict of interest}

The author declares no conflict of interest.

\section{References}

1. Foytik J. California apricot industry trends and outlook. California Agricultural Experiment Station Circular. 1961;495:1-31.
2. Holcomb R. Agricultural Statistics 2015. USA: USDA National Agricultural Statistics Service; 2015. pp. 1-520.

3. Hesse CO. Apricot culture in California. California Agricultural Experiment Station Circular. 1952;412:1-58.

4. Tufts WP. Interesting facts about apricots. The Blue Anchor. 1960;37(5):12-13.

5. Weinberger $\mathrm{JH}$. Notice to fruit growers and nurserymen relative to the naming and release of the Castleton apricot. USDA/ARS Variety Release Notice; 1963.

6. Anderson FW. Apricot tree. PP02877, USA: United States Plant Patent; 1969.

7. Sidnam B. Gardening Apricots challenge to southland gardeners. Special to the Times; 1994.

8. Ramos DE, Moller WJ, English H. Production and dispersal of ascospores of Eutypa armeniacae in California. Phytopathol. 1975;65: $1364-1371$

9. Weinberger JH. Chilling requirements of peach varieties. Proceedings of the American Society for Horticultural Science. 1950;56:122-128.

10. Anon. Riverside County agricultural production report 2014; 2014. 